\title{
Serum concentration and immunostaining of vascular endothelial growth factor in dogs with multicentric lymphoma
}

\author{
Concentração sérica e imunomarcação do fator de crescimento do \\ endotélio vascular em cães com linfoma multicêntrico
}

\author{
Sabrina Marin Rodigheri ${ }^{1 *}$; Sabryna Gouveia Calazans²; Reneé Laufer Amorim³; \\ Andrigo Barboza De Nardi ${ }^{4}$; Júlio Lopes Sequeira ${ }^{3}$; Carlos Roberto Daleck ${ }^{4}$
}

\begin{abstract}
Vascular endothelium growth factor (VEGF) is one of the most specific regulators of tumor angiogenesis and lymphangiogenesis. Moreover, VEGF plays a role in tumorigenesis through activation of an autocrine signaling pathway that enables cancer cells to stimulate their own growth. The aim of this study was to investigate VEGF serum levels and immunoexpression in canine multicentric lymphomas and correlate these parameters with the prognostic factors of this cancer. Sixteen dogs were evaluated (eight clinically healthy and eight diagnosed with multicentric lymphoma). The animals underwent blood sampling to measure VEGF serum concentrations and lymph node biopsy to evaluate VEGF immunoexpression. The VEGF immunoreactivity score was higher $(p=0.0003)$ in the lymph nodes of dogs with multicentric lymphoma (8.50 \pm 2.33$)$ than in those of healthy dogs $(1.87 \pm 1.80)$. There was no significant difference in the VEGF serum concentrations between healthy dogs and dogs with lymphoma $(p=0.08)$. Immunophenotype, clinical stage and grade of malignancy influenced the life expectancy of dogs with lymphoma. Our results showed that VEGF is expressed in high amounts in the lymph nodes of dogs with multicentric lymphoma and may be responsible for the growth, survival and migration of tumor cells.
\end{abstract}

Key words: Oncology, angiogenesis, lymphangiogenesis, tumorigenesis, VEGF

\section{Resumo}

O fator de crescimento do endotélio vascular (VEGF) é um dos mais específicos reguladores da angiogênese e da linfangiogênese tumoral, além de influenciar na tumorigênese mediante ativação de um circuito de sinalização autócrina que permite que as células neoplásicas estimulem seu próprio crescimento. O objetivo desse estudo foi investigar os níveis séricos e a imunomarcação do VEGF nos linfomas multicêntricos caninos e correlacionar esses parâmetros com fatores prognósticos da neoplasia. Foram avaliados 16 cães, sendo oito clinicamente sadios e oito com diagnóstico de linfoma multicêntrico. Os animais foram submetidos à coleta de sangue para mensuração da concentração sérica do VEGF e biopsia de linfonodo para avaliação da imunomarcação do VEGF. O escore de imunomarcação do VEGF foi superior $(\mathrm{p}=0,0003)$ nos linfonodos de cães com linfoma multicêntrico

\footnotetext{
${ }^{1}$ Discente do Programa de Pós-graduação em Cirurgia Veterinária, Faculdade de Ciências Agrárias e Veterinárias, Universidade Estadual Paulista Júlio de Mesquita Filho, FCAV/UNESP, Jaboticabal, SP, Brasil. E-mail: smrodigheri@yahoo.com.br

${ }^{2}$ Prof ${ }^{a}$, Universidade de Franca, UNIFRAN, Franca, SP, Brasil. E-mail: sgcalazans@gmail.com

3 Profs., Faculdade de Medicina Veterinária e Zootecnia, Universidade Estadual Paulista, FMVZ/UNESP, Botucatu, SP, Brasil. E-mail: renee@fmvz.unesp.br; sequeira@fmvz.unesp.br

${ }^{4}$ Profs., Faculdade de Ciências Agrárias e Veterinárias, Universidade Estadual Paulista Júlio de Mesquita Filho, FCAV/UNESP, Jaboticabal, SP, Brasil. E-mail: andrigo@fcav.com.br; daleck@fcav.unesp.br

* Author for correspondence
} 
$(8,50 \pm 2,33)$ em comparação ao escore dos linfonodos de cães sadios $(1,87 \pm 1,80)$. Não houve diferença significativa entre as concentrações séricas do VEGF de cães sadios e de cães com linfoma $(p=0,08)$. Imunofenótipo, estadiamento clínico e grau de malignidade influenciaram na sobrevida dos cães com linfoma. Os resultados obtidos permitiram concluir que o VEGF está expresso em quantidades elevadas nos linfonodos de cães com linfoma multicêntrico, podendo ser responsável pelo crescimento, sobrevivência e migração das células tumorais.

Palavras-chave: Oncologia, angiogênese, linfangiogênese, tumorigênese, VEGF

\section{Introduction}

Lymphomas are a heterogeneous group of cancers derived from lymphoid cells. They are commonly diagnosed in dogs, representing seven to $24 \%$ of canine cancers and $83 \%$ of hematopoietic tumors. Multicentric lymphoma is the anatomical form exhibiting the highest prevalence in dogs. It is characterized by varying degrees of involvement of the lymphoreticular system, and it can affect the lymph nodes, liver, spleen and bone marrow (VAIL et al., 2013).

Several studies have been performed to identify the prognostic factors associated with a therapeutic response, remission period and life expectancy in dogs with multicentric lymphoma. The main factors investigated include age, sex, breed, weight, clinical stage, cell morphology and immunophenotype (GREENLEE et al., 1990; TESKE et al., 1994).

The survival of tumor cells in a microenvironment is dependent on sufficient amounts of oxygen and nutrients and on the cell's ability to eliminate toxins (CASTRO JÚNIOR et al., 2006). Angiogenesis is a process that leads to the formation of new blood vessels from an existing vascular bed, and it is essential for cancer growth and progression (FOLKMAN, 1995). Lymphatic vessels are also important components of the tumor microenvironment because they act directly on tissue homeostasis and immunosurveillance and constitute the mechanism for the metastatic spread of cancer to local lymph nodes and distant organs (WRÓBEL et al., 2006).

Vascular endothelial growth factor (VEGF) is considered one of the most important mediators of tumor angiogenesis and lymphangiogenesis (HIRAKAWA et al., 2005). VEGF is a multifunctional glycoprotein that stimulates mitogenic activity in endothelial cells, vascular permeability, cell survival and the production of several molecules involved in neovascularization processes (FERRARA, 2004).

Recent studies have revealed that VEGF production by tumor cells and the activation of VEGF receptors on the surface of cancer cells activates an autocrine signaling pathway that enables cancer cells to stimulate their own growth, survival and migration. Thus, it is believed that VEGF may act in tumorigenesis, regardless of angiogenesis and lymphangiogenesis (SENGER, 2010; PERROTAPPLANAT; DI BENEDETTO, 2012; CAO et al., 2012).

Immunostaining and increased serum concentrations of VEGF have been found in different solid and hematopoietic cancers in humans (FERRARA, 2004; PERROTAPPLANAT; DI BENEDETTO, 2012; DUSE et al., 2013). In dogs, VEGF expression is evident in malignant mammary gland tumor (MAIOLINO et al., 2000), squamous cell carcinoma (RESTUCCI et al., 2003), poorly differentiated seminoma (MILLANTA et al., 2006), meningioma (PLATT et al., 2006), mast cell tumor (REBUZZI et al., 2007), oral melanoma (TAYLOR et al., 2007) and lymphoma (WOLFESBERGER et al., 2008) cells. Studies have shown elevated plasma concentrations of VEGF in dogs with hemangiosarcoma and lymphoma (CLIFFORD et al., 2001; GENTILINI et al., 2005; ARESU et al., 2012). 
Given the high incidence of lymphoma in dogs and the association of VEGF with the induction and progression of cancer, this study aimed to investigate the serum concentration and immunostaining of VEGF in dogs with multicentric lymphoma and correlate these parameters with the main prognostic factors of this cancer.

\section{Materials and Methods}

A total of 16 dogs, including males and females of different sizes, with or without a defined breed, were selected. Of these, eight dogs were clinically healthy, and eight were diagnosed with multicentric lymphoma through cytological analysis of the lymph nodes. Blood was collected from the animals for a complete blood count, biochemical serum evaluation (alanine aminotransferase and creatinine) and quantification of VEGF serum concentration. Additionally, excisional biopsy of the popliteal lymph node was performed for VEGF immunostaining. Samples from the dogs with lymphoma were collected at the time of diagnosis, prior to any treatment.

In dogs with lymphoma, chest X-ray, abdominal ultrasound and bone marrow cytology were performed to determine the cancer stage, according to the protocol proposed by the World Health Organization (GREENLEE et al., 1990). Popliteal lymph node samples were used to determine the histopathological classification (degree of malignancy) according to the Kiel System, and the neoplasm immunophenotype was determined through immunohistochemistry.

Blood samples from animals were obtained by jugular venipuncture, and the serum was separated and stored at $-20^{\circ} \mathrm{C}$. VEGF serum concentrations were quantified using a commercial sandwich enzyme-linked immunosorbent assay (ELISA) kit (Human VEGF-C Immunoassay, Quantikine $^{\mathrm{R}}$, R\&D Systems, Minneapolis, USA) following the manufacturer's instructions. For this assay, a monoclonal antibody in solid phase and a peroxidase-conjugated polyclonal antibody against recombinant human VEGF were used. All of the samples were assayed in duplicate. The optical density was determined at $450 \mathrm{~nm}$ using a microplate reader. The VEGF serum concentration was determined by linear regression analysis. Validation of the ELISA test using the human antibody to quantify canine vascular endothelial growth factor has been confirmed in previous studies (SCHEIDEGGER et al., 1999).

For immunohistochemistry, 3-micron-thick sections of paraffin-embedded specimens were placed on slides previously treated with a liquid organosilane-based adhesive (A3648 - SIGMA). The slides were kept in an incubator at $60^{\circ} \mathrm{C}$ for 24 hours and then subjected to deparaffinization, hydration, antigen recovery and endogenous peroxidase blocking. To determine the VEGF immunoreactivity, an anti-VEGF monoclonal antibody (Cat. No. M7273, DakoCytomation ${ }^{\circledR}$ ) at a 1:25 dilution and the Envision Dual Link kit (Cat. No. K4063, DakoCytomation) were used. Signal development was performed with the chromogenic substrate diaminobenzidine (DAB - Dako - Cat. No. K34466). For lymphoma immunophenotyping, anti-CD3 (Cat. No. A0452, DakoCytomation ${ }^{\circledR}$ ) and anti-CD79 (Cat. No. M7050, DakoCytomation ${ }^{\circledR}$ ) primary antibodies were used. The slides were examined by light microscopy. Negative controls were included for all of the reactions: the primary antibody was replaced by immunoglobulins (Igs) from the animal species in which the primary antibody was raised (rabbit CD3-Igs; mouse CD79a and VEGF-Igs).

To determine the VEGF immunostaining, five fields of each sample were analyzed at 40x magnification. In each field, the percentage of stained cells (Table 1) and the staining intensity (weak $=1$, moderate $=2$ or strong $=3$ ) were measured. The mean was determined for each field, and a score from zero to 12 was obtained from the product of the score of the percentage of labeled cells by the staining intensity score. 
Table 1. Score attributed to the percentage of cells stained with anti-VEGF antibody in the lymph nodes of healthy dogs and dogs with multicentric lymphoma.

\begin{tabular}{cc}
\hline Percentage of stained cells & Score \\
\hline$<5 \%$ & 0 \\
$5-25 \%$ & 1 \\
$26-50 \%$ & 2 \\
$51-75 \%$ & 3 \\
$>75 \%$ & 4 \\
\hline
\end{tabular}

After the tests and sample collection, all of the animals diagnosed with multicentric lymphoma underwent antineoplasm chemotherapy with L-asparaginase, vincristine sulfate, cyclophosphamide, doxorubicin and prednisone (VAIL et al., 2013). The survival period from diagnosis to death was recorded for each animal.

Data were subjected to the Cramér-von Mises test for the normality of residuals and then to the multiple comparison test. For group comparisons, the Mann Whitney test was used. The Kruskal-Wallis test and Dunn's post test were used to compare the different clinical stages. The correlation between the animals' survival and the VEGF immunostaining and serum concentration was assessed through the Spearman test. KaplanMeier survival testing was performed to assess the association between survival and clinical stage. For all of the tests, differences were considered significant when $\mathrm{p}<0.05$.

\section{Results}

In the current study, multicentric lymphoma was diagnosed in eight dogs aged four to 15 years, with five females and three males. The distribution of dogs with lymphoma in regard to age, sex, clinical stage, degree of malignancy, immunophenotype, serum concentration of VEGF, score of VEGF immunostaining and survival time are shown in Table 2.

Table 2. Identification, age, sex, clinical stage, degree of malignancy, VEGF serum concentration, VEGF immunostaining score and survival time in dogs with multicentric lymphoma.

\begin{tabular}{ccccccccc}
\hline ID & $\begin{array}{c}\text { Age } \\
\text { (years) }\end{array}$ & Sex & CS & IP & DM & $\begin{array}{c}\text { VEGF serum } \\
\text { concentration (pg/mL) }\end{array}$ & $\begin{array}{c}\text { VEGF } \\
\text { Score }\end{array}$ & $\begin{array}{c}\text { Survival } \\
\text { (days) }\end{array}$ \\
\hline 1 & 7 & M & V & B & Low & 0.00 & 6 & 10 \\
2 & 10 & M & V & T & High & 0.00 & 8 & 7 \\
3 & 3 & F & III & B & High & 149.86 & 12 & 240 \\
4 & 4 & M & V & T & High & 13.06 & 8 & 5 \\
5 & 4 & F & III & B & Low & 35.86 & 8 & 320 \\
6 & 4 & F & III & B & High & 58.66 & 8 & 30 \\
7 & 5 & F & IV & B & High & 172.66 & 6 & 30 \\
8 & 15 & F & IV & B & High & 252.46 & 12 & 30 \\
\hline
\end{tabular}

ID: animal identification. CS: clinical stage. IP: immunophenotype. DM: degree of malignancy.

For sex, M: male, F: female.

No animals were classified as stages I and II, lymphomas. Regarding the immunophenotype, three dogs $(37.5 \%)$ were classified as stage III, two animals $(25 \%)$ had T-cell lymphoma (hightwo (25\%) as stage IV and three (37.5\%) as stage level), and six (75\%) had B-cell lymphoma V. Two dogs $(25 \%)$ had low-grade malignant (two with low-grade and four with high-grade lymphoma, and six (75\%) had highly malignant malignant lymphomas). 
Serum concentrations of VEGF ranged from lymphoma (47.26) was higher than the mean found 0 to $58.66 \mathrm{pg} / \mathrm{mL}$ in healthy dogs and from 0 to in healthy dogs $(0.00)$, there was no significant $252.46 \mathrm{pg} / \mathrm{mL}$ in dogs with lymphoma. Although difference between the two groups $(\mathrm{p}=0.08)$ the mean VEGF serum concentration in dogs with (Figure 1).

Figure 1. Comparison of VEGF serum concentrations $(\mathrm{pg} / \mathrm{mL})$ in healthy dogs and dogs with multicentric lymphoma $(\mathrm{p}=0.08)$.

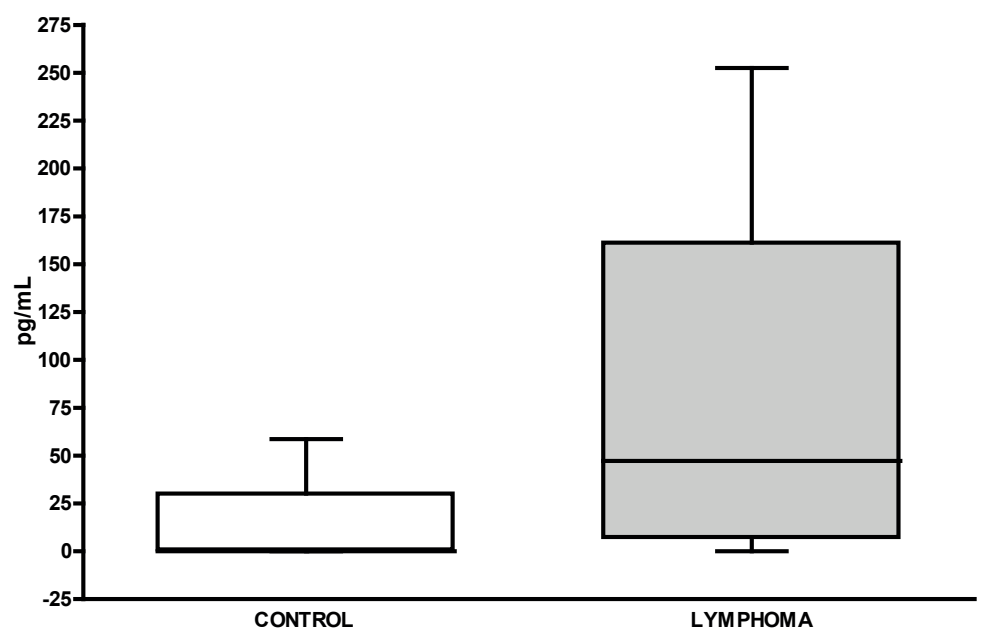

Acorrelation between VEGF serumconcentration Dogs at stage IV showed higher VEGF serum and the clinical stage in dogs with multicentric concentrations than dogs at stages III ( $p>0.05)$ and lymphoma was identified $(\mathrm{p}=0.04)$ (Figure 2). $\mathrm{V}(\mathrm{p}<0.05)$.

Figure 2. Comparison between VEGF serum concentration and the clinical stage of canine multicentric lymphomas $(\mathrm{p}=0.04)$.

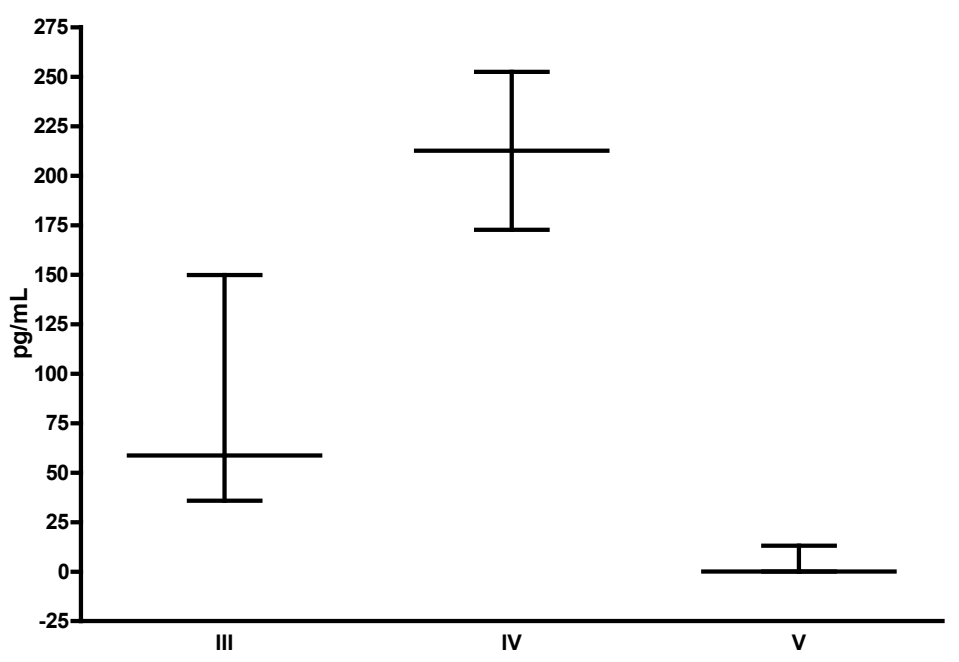


On immunohistochemistry, the VEGF lymphocytes. In the lymph nodes of healthy dogs, immunostaining score was significantly higher VEGF immunostaining was observed in $87.5 \%$ of $(\mathrm{p}=0.0003)$ in the lymph nodes of dogs with lymphoma (8.50 \pm 2.33$)$ than in the lymph nodes of healthy dogs $(1.87 \pm 1.80)$ (Figure 3$)$.

the cases, with scores between 0 and 6 (Figure 4). In dogs with lymphoma, VEGF immunostaining was found in $100 \%$ of cases, with scores between 6 and 12 (Figure 5).

Figure 3. Comparison of VEGF immunostaining scores in the lymph nodes of healthy dogs and dogs with multicentric lymphoma $(\mathrm{p}=0.0003)$.

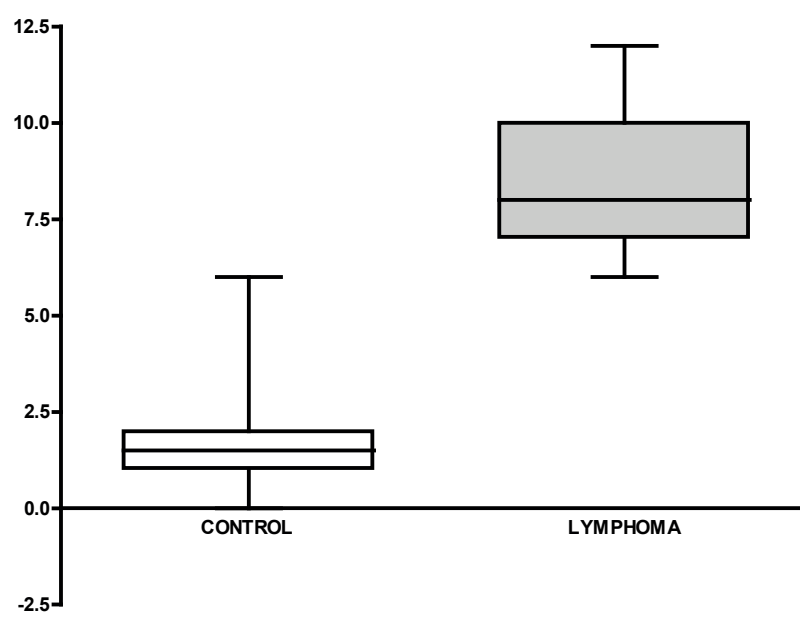

VEGF expression was characterized by diffuse cytoplasmic staining in normal and neoplastic

Figure 4. Photomicrograph of a lymph node from a healthy dog. Positivity for anti-VEGF primary antibody is observed in less than $25 \%$ of the lymphocytes, characterizing a score of 1 . EnVision, 3,3'-diaminobenzidine (DAB), Mayer hematoxylin. Magnification: 400X.

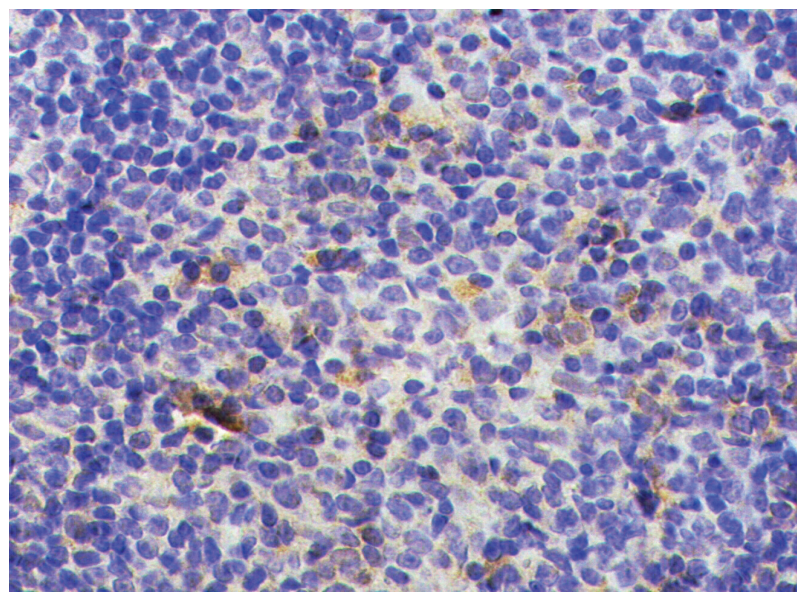

Figure 5. Photomicrograph of a lymph node from a dog with lymphoma. Positivity for anti-VEGF primary antibody was observed in over $75 \%$ of neoplastic lymphocytes, characterizing a score of 8 . EnVision, 3,3'-diaminobenzidine (DAB), Mayer hematoxylin. Magnification: 400X.

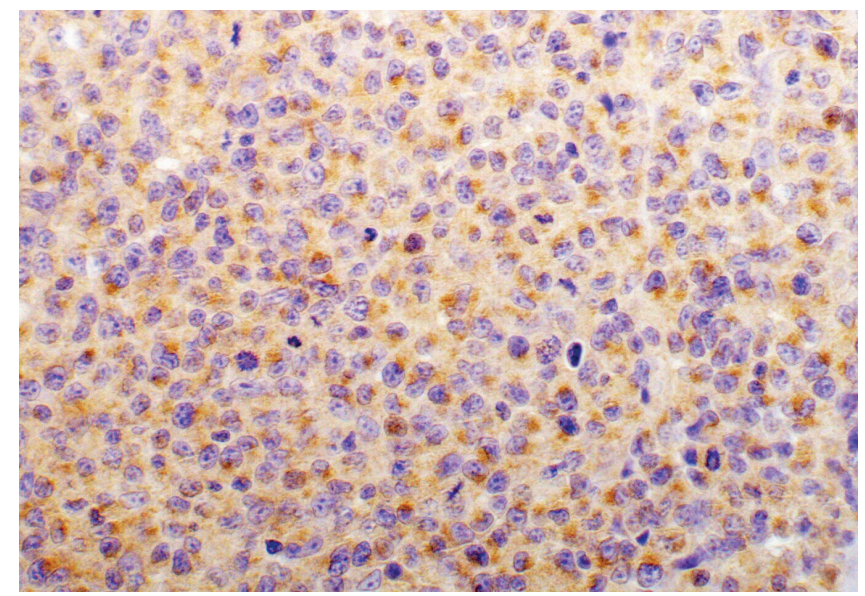

No correlation was found between the VEGF immunostaining score and clinical stage in dogs with multicentric lymphoma $(\mathrm{p}=1.00)$. Moreover, there was no correlation between VEGF serum 
concentration and VEGF immunostaining score $(p=0.2250)$. It was also not possible to establish a correlation between serum concentration and VEGF immunostaining with the immunophenotype and the degree of malignancy of lymphomas due to the predominance of animals with high-grade malignant lymphomas and immunophenotype B.

The survival time of the animals ranged from five to 320 days, and $62.5 \%$ of the animals $(n=5)$ survived less than 35 days. No correlation was observed between survival time and VEGF serum concentration $(\mathrm{p}=0.61)$ or immunostaining $(p=1.02)$ in dogs with multicentric lymphoma. It was observed that dogs with T-cell lymphoma had a significantly shorter life expectancy than dogs with B-cell lymphoma ( $p=0.0039)$. Moreover, dogs diagnosed with advanced neoplasm stages (stages IV and V) had the lowest survival rates.

\section{Discussion}

Although it is well known that the growth and spread of solid tumors require intense neovascularization, the influence of angiogenesis and lymphangiogenesis in the progression of hematopoietic neoplasms is not yet clear (BERTOLINI et al., 1999; GILES et al., 2004; KOSTER; RAEMAEKERS, 2005; HIRAKAWA et al., 2007; KOPIC et al., 2011).

Researchers have found a correlation between VEGF expression and prognostic factors for nonHodgkin's human lymphomas, concluding that VEGF immunostaining may be an effective method to evaluate the biological behavior of lymphomas (HAZAR et al., 2003; KORKOLOPOULOU et al., 2005).

In the current study, $75 \%$ of canine multicentric lymphoma samples showed high scores [8, 9 or 12] on VEGF immunostaining. VEGF immunostaining has been detected in $33.8 \%$ of human patients with non-Hodgkin's lymphoma (HAZAR et al., 2003). Wolfesberger et al. (2007) found high levels of VEGF expression in $60 \%$ of canine lymphoma samples. Out of the six animals with high immunostaining scores, five (83\%) had highgrade malignant lymphomas. The expression of VEGF was also evaluated in different histological types of human non-Hodgkin's lymphoma, where higher immunoreactivity was found in biologically aggressive tumors (JORGENSEN, 2005).

Upon evaluating normal lymph nodes, a lack of VEGF immunostaining was observed only in one sample. Six samples (75\%) showed lower immunostaining scores (1 and 2) and one (12.5\%) presented a moderate immunostaining score (6). Wolfesberger et al. (2007) also observed VEGF immunostaining in normal lymph nodes of dogs, suggesting that VEGF expression may be required to maintain the physiological microcirculation of lymph nodes.

In the immunohistochemical technique employed here, anti-VEGF-A monoclonal antibody was used, which is an important inducer of tumor angiogenesis and lymphangiogenesis (RUAN et al., 2009). Our results showed that the VEGF-A immunostaining score was significantly higher $(p=0.0003)$ in the lymph nodes of dogs with lymphoma compared with the lymph nodes of healthy dogs.

Wolfesberger et al. (2008) found a significant difference between VEGF expression in the lymph nodes of healthy dogs and dogs with lymphoma. Kopic et al. (2011) reported a greater number of blood vessels in the lymph nodes of individuals with lymphoma compared with reactive lymph nodes in addition to finding a positive correlation between tumor vasculature and the degree of malignancy for non-Hodgkin's lymphomas. Studies have also shown the importance of lymphangiogenesis in multicentric lymphoma because neoplastic lymphoid cells invade the lymph nodes and other organs through lymphatic vessels (HIRAKAWA et al., 2005; KADOWAKI et al., 2005; WRÓBEL et al., 2006). 
In the present study, no correlation was observed between VEGF immunostaining and the clinical stage and life expectancy of dogs with multicentric lymphoma. Similar results have been obtained by a few researchers who reported significantly greater tumor remission rates in patients with negative VEGF immunostaining but found no correlation between VEGF expression, vascular microdensity, patient's sex and age, clinical stage, degree of malignancy and patient survival (HAZAR et al., 2003). A recent study showed VEGF immunostaining in $79 \%$ of canine lymphoma samples; however, no correlation was found between VEGF immunostaining and animal survival (WOLFESBERGER et al., 2012).

In patients with cancer, VEGF may originate from cancer cells, tumor-infiltrating inflammatory cells or circulating inflammatory cells. It is believed that VEGF present in the tumor microenvironment may move to the circulation and accumulate in lymphocytes and platelets (SALVEN et al., 1997). Studies show that VEGF detected in serum samples is released from blood cells during the coagulation process (SALVEN et al., 2000).

Salven et al. (1997) found that patients with lymphoma exhibit significantly higher VEGF serum concentrations than healthy people. Furthermore, they demonstrated a negative influence of high serum VEGF concentration on patient survival. Giles et al. (2004) observed increased serum levels of VEGF in patients with lymphoma without chemotherapy. Additionally, they showed that life expectancy was significantly longer in patients with below-average VEGF concentration before chemotherapy.

In the present study, the VEGF serum concentrations ranged from 0 to $58.66 \mathrm{pg} / \mathrm{mL}$ in healthy dogs and from 0 to $252.46 \mathrm{pg} / \mathrm{mL}$ in dogs with multicentric lymphoma. In a previous study, changes from 0 to $23.28 \mathrm{pg} / \mathrm{mL}$ were observed in healthy dogs and from 0 to $189.84 \mathrm{pg} / \mathrm{mL}$ in dogs with lymphoma (GENTILINI et al., 2005). The lack of a correlation between VEGF serum concentration and VEGF immunostaining show that circulating levels of VEGF do not reflect the tumor microenvironment.

Salven et al. (2000) found that the VEGF serum concentration may vary from undetectable to $1290 \mathrm{pg} / \mathrm{mL}$ in a study performed with people with non-Hodgkin's lymphoma, where one-third of patients had concentrations equal to or greater than $390 \mathrm{pg} / \mathrm{mL}$. Moreover, they found that serum concentrations of VEGF and basic fibroblast growth factor (bFGF) are prognostic factors that negatively influence patient survival. Other researchers found that elevated serum levels of VEGF and interleukin-6 before chemotherapy are associated with low survival rates in people with non-Hodgkin's lymphoma (NIITSU et al., 2002). In the present study, no significant correlation between VEGF serum concentration and survival in dogs with multicentric lymphoma was observed. The small number of dogs with lymphoma evaluated here might have led to type 2 error.

High VEGF serum concentrations in dogs diagnosed with stage III or IV neoplasm and low serum levels in dogs diagnosed with stage $\mathrm{V}$ was found. Salven et al. (2000) showed no correlation between serum concentrations of VEGF and the clinical stage of human non-Hodgkin's lymphomas. In a study using dogs, a significant correlation between VEGF serum levels and substage "b" lymphomas was found (GENTILINI et al., 2005).

Wolfesberger et al. (2008) reported significantly higher VEGF plasma levels in dogs with T-cell lymphoma and high-grade malignant lymphomas. Here, it was not possible to establish a correlation between VEGF serum concentration and the immunophenotype and degree of malignancy of lymphomas due to the predominance of animals with highly malignant lymphomas and immunophenotype B.

The average lifespan of a dog with multicentric lymphoma is 60 days without chemotherapy and 360 days with systemic polychemotherapy. The high incidence of canine lymphoma and low life 
expectancy suggest that new therapeutic approaches are needed to increase the lifespan of affected animals (VAIL et al., 2013).

In the present study, the survival time of dogs ranged between five and 320 days (mean of 120 days). The prevalence of high-grade malignant lymphomas in advanced stages (III, IV and IV) may explain the low life expectancy of the animals. The two dogs with T-cell lymphoma diagnosed with more advanced stages of the neoplasm (stage V) exhibited a survival time shorter than 10 days. The immunophenotype, clinical stage and the degree of malignancy may influence the therapeutic response and life expectancy of canine lymphoma (VAIL et al., 2013).

Several studies on tumor angiogenesis and lymphangiogenesis have been developed aiming to detect biomarkers to aid in the early diagnosis, prognosis and treatment of different neoplasms (LAMONTAGNE, 2005). There have been advances in treatments involving the inhibition of tumor angiogenesis and VEGF blocking in human cancer therapy (FERRARA, 2004). The anti-VEGF monoclonal antibody bevacizumab inhibits tumor angiogenesis by blocking binding of VEGF to VEGFR-1 and VEGFR-2 receptors; however, it does not inhibit binding of VEGF to neurophilin, a VEGF receptor predominantly expressed in tumor cells. This mechanism of action explains the inefficacy of controlling tumor progression with the use of bevacizumab only in different types of neoplasms (VAN METER; KIM, 2010).

Studies have shown that the growth and progression of lymphomas are mediated by two mechanisms: autocrine stimulation of tumor cells via the expression of VEGF and its receptors by neoplastic cells, and the paracrine effect of a pro-angiogenic tumor microenvironment (CAO et al., 2012).

\section{Conclusions}

Although VEGF did not prove to be a significant prognostic factor, it is involved in the development of canine multicentric lymphomas. Thus, further studies should be performed to clarify the roles of VEGF signaling pathways in canine lymphoma, allowing the development of more effective therapies.

\section{Acknowledgements}

We thank the FAPESP (Fundação de Amparo a Pesquisa do Estado de São Paulo) for the financial support and the veterinary physician Evandro Zacché (Ph.D.) for helping with the statistical analysis.

\section{Ethics committee}

This study was performed with the approval of the Animal Ethics and Welfare Committee of the School of Agricultural and Veterinary Sciences (Faculdade de Ciências Agrárias e Veterinárias - FCAV) of the São Paulo State University (Universidade Estadual Paulista - UNESP), Jaboticabal, SP, Brazil.

\section{References}

ARESU, L.; ARICO, A.; COMAZZI, S.; GELAIN, M. E.; RIONDATO, F.; MORTARINO, M.; MORELLO, E.; STEFANELLO, D.; CASTAGNARO, M. VEGF and MMP-9: biomarkers for canine lymphoma. Veterinary and Comparative Oncology, Oxford, v. 12, n. 1, p. 29-36, 2012.

BERTOLINI, F.; PAOLUCCI, M.; PACCATORI, F.; CINIERI, S.; AGAZZI, A.; FERRUCCI, P. F.; COCOROCCHIO, E.; GOLHIRSCH,A.; MARTINELLI, $\mathrm{G}$. Angiogenic growth factors and endostatin in nonHodgkin's lymphoma. British Journal of Haematology, Oxford, v. 106, n. 2, p. 504-509, 1999.

CAO, Y.; E, G.; WANG, E.; PAL, K.; DUTTA, S. K.; BAR-SAGI, D.; MUKHOPADHYAY, D. VEGF exerts an angiogenesis-independent function in cancer cells to promote their malignant progression. Cancer Research, Philadelphia, v. 72, n. 16, p. 3912-3918, 2012. 
CASTRO JÚNIOR, G.; PUGLISI, F.; AZAMBUJA, E.; EL SAGHIR, N. S.; AWADA, A. Angiogenesis and Cancer: a cross-talk between basic science and clinical trials (the "do ut des" paradigm). Critical Reviews in Oncology/Hematology, Ireland, v. 59, n. 1, p. 40-50, 2006.

CLIFFORD, C. A.; HUGHES, D.; BEAL, M. W.; MACKIN, A. J.; HENRY, C. J.; SHOFER, F. S.; SORENMO, K. U. Plasma vascular endothelial growth factor concentrations in healthy dogs and dogs with hemangiosarcoma. Journal of Veterinary Internal Medicine, Philadelphia, v. 15, n. 2, p. 131-135, 2001.

DUSE, A. O.; CEASU, R. A.; CIMPEAN, T. M. A. M.; GAJE, P.; IONITA, H.; JUNG, I.; RAICA, M. Expression and possible significance of vascular endothelial growth factor in non-Hodgkin lymphoma. Archives in Biological Science, Belgrade, v. 65, n. 2, p. 487-491, 2013.

FERRARA, N. Vascular endothelial growth factor: basic science and clinical progress. Endocrine Reviews, Baltimore, v. 25, n. 4, p. 581-611, 2004.

FOLKMAN, J. Angiogenesis in cancer, vascular, rheumatoid and other disease. Nature Medicine, New York, v. 1, n. 27, p. 27-30, 1995.

GENTILINI, F.; CALZOLARI, C.; TURBA, M. H.; AGNOLI, C.; FAVA, D.; FORNI, M.; BERGAMINI, P. F. Prognostic value of serum vascular endothelial growth factor (VEGF) and plasma activity of matrix metalloproteinase (MMP) 2 and 9 in lymphoma-affected dogs. Leukemia Research, Oxford, v. 29, n. 11, p. 12631269, 2005.

GILES, F. J.; VOSE, J. M.; DO, K. A.; JOHNSON, M. M.; MANSHOURI, T.; BOCIEK, G.; BIERMAN, P. J.; O' BRIEN, S. M.; KANTARJIAN, H. M.; ARMITAGE, J. O.; ALBITAR, M. Clinical relevance of circulating angiogenic factors in patients with non-Hodgkin's lymphoma or Hodgkin's lymphoma. Leukemia Research, Oxford, v. 28, n. 6, p. 595-604, 2004.

GREENLEE, P. G.; FILIPPA, D. A.; QUIMBY, F. W.; PATNAIK, A. K.; CALVANO, S. E.; MATUS, R. E.; KIMMEL, M.; HURVITZ, A. I.; LIEBERMAN, P. H. Lymphoma in dogs: a morphologic, immunologic and clinical study. Cancer, Hoboken, v. 66, n. 3, p. 480-490, 1990.

HAZAR, B.; PAYDAS, S.; ZORLUDEMIR, S.; SAHIN, B.; TUNCER, I. Prognostic significance of microvessel density and vascular endothelial growth factor (VEGF) expression in non-Hodgkin's lymphoma. Leukemia \& Lymphoma, London, v. 44, n. 12, p. 2089-2093, 2003.

HIRAKAWA， S.; BROWN， L. F.; KODAMA， S.; PAAVONEN, K.; ALITALO, K.; DETMAR, M.
VEGF-C induced lymphangiogenesis in sentinel lymph nodes promotes tumor metastasis to distant sites. Blood, New York, v. 109, n. 3, p. 1010-1017, 2007.

HIRAKAWA, S.; KODAMA, S.; KUNSTFELD, R.; KAJIYA, K.; BROWN, L. F.; DETMAR, M. VEGF-A induces tumor and sentinel lymph node lymphangiogenesis and promotes metastasis. The Journal of Experimental Medicine, New York, v. 201, n. 7, p. 1089-1099, 2005.

JORGENSEN, J. M. The role of angiogenesis in non-Hodgkin lymphoma. Danish Medical Bulletin, Copenhagen, v. 52, n. 4, p. 254-254, 2005.

KADOWAKI, I.; ICHINOHASAMA, R.; HARIGAE, H.; ISHIZAWA, K.; OKITSU, Y.; KAMEOKA, J.; SASAKI, T. Accelerated lymphangiogenesis in malignant lymphoma: possible role of VEGF-A and VEGF-C. British Journal of Haematology, Oxford, v. 130, n. 6, p. 869-877, 2005.

KOPIC, E.; CICKUSIC, E.; KOPIC, A.; ARNAUTOVICCUSTOVIC, A.; HALILBASIC, A.; TINJIC, L.; HASIC, S.; SIMENDIC, V. Morphometric angiogenesis parameters for indolent and aggressive non-Hodgkin's lymphoma. Medical Archives, Sarajevo, v. 65, n. 1, p. 9-12, 2011.

KORKOLOPOULOU,P.;THYMARA,I.;KAVANTZAS, N.; VASSILAKOPOULOS, T. P.; ANGELOPOULOU, M. K.; KOKORIS, S. I.; DIMITRIADOU, E. M.; SIAKANTARIS, M. P.; ANARGYROU, K.; PANAYIOTIDIS, P.; TSENGA, A.; ANDROULAKI, A.; DOUSSIS-ANAGNOSTOPOULOU, I. A.; PATSOURIS, E.; PANGALIS, G. A. Angiogenesis in Hodgkin's lymphoma: a morphometric approach in 286 patients with prognostic implications. Leukemia, Baltimore,,v. 19, n. 1, p. 894-900, 2005.

KOSTER, A.; RAEMAEKERS, J. M. M. Angiogenesis in malignant lymphoma. Current Opinion in Oncology, Philadelphia, v. 17, n. 6, p. 611-616, 2005.

LAMONTAGNE, K. Antiangiogenesis: new frontiers in therapeutic development. Angiogenesis, London, v. 8, n. 4, p. 285-287, 2005.

MAIOLINO, P.; DE VICO, G.; RESTUCCI, B. Expression of vascular endothelial growth factor in basal cell tumours and in squamous cell carcinomas of canine skin. Journal of Comparative Pathology, London, v. 123, n. 2, p. 141-145, 2000.

MILlANTA, F.; SILVESTRI, G.; VASELLI, C.; CITI, S.; PISANI, G.; LORENZI, D.; POLI, A. The role of vascular endothelial growth factor and its receptor Flk/ $\mathrm{KDR}$ in promoting tumour angiogenesis in feline and canine mammary carcinomas: a preliminary study of 
autocrine and paracrine loops. Research in Veterinary Science, London, v. 81, n. 3, p. 350-357, 2006.

NIITSU, N.; OKAMOTO, M.; NAKAMINE, H.; YOSHINO, T.; TAMARU, J.; NAKAMURA, J.; HIGASHIHANA, M.; HIRANO, M. Simultaneous elevation of the serum concentrations of vascular endothelial growth factor and interleukin- 6 as independent predictors of prognosis in agressive non-Hodgkin's lymphoma. European Journal of Haematology, Austin, v. 68, n. 2, p. 91-100, 2002.

PERROT-APPLANAT, M.; DI BENEDETTO, M. Autocrine functions of VEGF in breast tumor cells. Adhesion, survival, migration and invasion. Cell Adhesion \& Migration, Copenhagen, v. 6, n. 6, p. 547553, 2012.

PLATT, S. R.; SCASE, T. J.; ADAMS, V.; WIECZOREK, L.; MILLER, J.; ADAMO, F.; LONG, S. Vascular endothelial growth factor expression in canine intracranial meningiomas and association with patient survival. Journal of Veterinary Internal Medicine, Philadelphia, v. 20, n. 3, p. 663-668, 2006.

REBUZZI, L.; WILLMANN, M.; SONNECK, K.; GLEIXNER, K. V.; FLORIAN, S.; KONDO, R.; MAYERHOFER, M.; VALES, A.; GRUZE, A.; PICKL, W. F.; THALHAMMER, J. G.; VELENT, P. Detection of vascular endothelial growth factor (VEGF) and VEGF receptors Flt-1 and KDR in canine mastocytoma cells. Veterinary Immunology and Immunopathology, Amsterdam v. 115, n. 3-4, p. 320-333, 2007.

RESTUCCI, B.; MAIOLINO, P.; PACIELLO, O.; MARTANO, M.; DE VICO, G.; PAPPARELLA, S. Evaluation of angiogenesis in canine seminomas by quantitative immunohistochemistry. Journal of Comparative Pathology, London, v. 128, n. 4, p. 252259, 2003.

RUAN, J.; HAJJAR, K.; HAFFI, S.; LEONARD, J. $\mathrm{P}$. Angiogenesis and antiangiogenic therapy in nonHodgkin's lymphoma. Annals of Oncology, London, v. 20, n. 3, p. 413-424, 2009.

SALVEN, P.; ORPANA, A.; TEERENHOVI, L.; JOENSUU, H. Simultaneous elevation in the serum concentrations of the angiogenic growth factors VEGF and bFGF is an independent predictor of poor prognosis in non-Hodgkin's lymphoma: a single institution study of 200 patients. Blood, New York,, v. 96, n. 12, p. 3712$3718,2000$.

SALVEN, P.; TEERENHOVI, L.; JOENSUU, H. A high pretreatment serum vascular endothelial growth factor concentration is associated with poor outcome in nonHodgkin's lymphoma. Blood, New York, v. 90, n. 8, p.
3167-3172, 1997.

SCHEIDEGGER, P.; WEIGLHOFER, W.; SUAREZ, S. Vascular endothelial growth factor (VEGF) and its receptors in tumor-bearing dogs. The Journal of Biological Chemistry, Rockville, v. 380, n. 12, p. 14491454, 1999.

SENGER, D. R. Vascular endothelial growth factor: much more than an angiogenesis factor. Molecular Biology of the Cell, Bethesda, v. 21, n. 3, p. 377-379, 2010.

TAYLOR, K. H.; SMITH, A. N.; HIGGINBOTHAM, M.; SCHWARTZ, D. D.; CARPENTER, D. M.; WHITLEY, E. M. Expression of vascular endothelial growth factor in canine oral malignant melanoma. Veterinary and Comparative Oncology, Oxford, v. 5, n. 4, p. 208-218, 2007.

TESKE, E.; VAN HEERDE, P.; RUTTEMAN, G. R.; KURZMAN, I. D.; MOORE, P. F.; MAC EWEN, G. Prognostic factors for treatment of malignant lymphoma in dogs. Journal of American Veterinary Medical Association, New York, v. 205, n. 12, p. 1722-1728, 1994.

VAIL, D. M.; PINKERTON, M. E.; YOUNG, K. M. Hematopoietic tumors. In: WITHROW, S. J.; VAIL, D. M.; PAGE, R. L. Small animal clinical oncology. $5^{\text {th }}$ ed. St. Louis: Saunders Elsevier, 2013. cap. 32, p. 608-638.

VAN METER, M. E.; KIM, E. S. Bevacizumab: current updates in treatment. Current Opinion in Oncology, Philadelphia, v. 22, n. 6, p. 586-591, 2010.

WOLFESBERGER, B.; GUIJADEARESPACOHAGAY, A.; WILLMANN, M.; GERNER, W.; MILLERY, I.; SCHWENDENWEINY, I.; KLEITER, M.; EGERBACHER, M.; THALHAMMER, J. G. MUELLAUER, L.; SKALICKYZ, M.; WALTER, I. Expression of vascular endothelial growth factor and its receptors in canine lymphoma. Journal of Comparative Pathology, London, v. 137, n. 1, p. 30-40, 2007.

WOLFESBERGER, B.; TONAR, Z.; FUCHSBAUMGARTINGER, A.; WALTER, I.; SKALICKY, M.; WITTER, K.; THALHAMMER, J. G.; PAGITZ, M.; KLEITER, M. Angiogenic markers in canine lymphoma tissues do not predict survival times in chemotherapy treated dogs. Research in Veterinary Science, London, v. 92, n. 3, p. 444-450, 2012.

WOLFESBERGER, B.; TONAR, Z.; WITTER, K.; GUIJA DE ARESPACOHAGAY, A.; SKALICKYZ, M.; WALTER, I.; THALHAMMER, J. G.; EGGER, G. F. Microvessel density in normal lymph nodes and lymphomas of dogs and their correlation with vascular endothelial growth factor expression. Research in Veterinary Science, London, v. 85, n. 1, p. 56-61, 2008. 
WRÓBEL, T.; MAZUR, G.; DZIEGIEL, P.; JELEN, M.; SZUBA, A.; KULICZKOWSKI, K.; ZABEL, M. Density of intranodal lymphatics and VEGF-C expression in B-cell lymphoma and reactive lymph nodes. Folia Histochemica et Cytobiologica, Gdansk, v. 44, n. 1, p. 43-47, 2006. 